\title{
Analysis of the Export Activity of Hungarian FinTech Companies*
}

\author{
Péter Fáykiss - Lívia Ónozó
}

In our analysis, we examine domestic FinTech SMEs by using micro-data, focusing on the export activity of companies in the Hungarian FinTech sector. Our study offers new content not only because of the range of examined enterprises, but also due to the uniqueness of the database used, as we have endeavoured to provide a deeper picture of domestic FinTech companies with the help of company data rarely used thus far. The purpose of our examination is twofold: first, based on the company characteristics that can be extracted from the annual accounts of the companies concerned, we organise the Hungarian FinTech companies into distinct groups by cluster analysis. Second, using logistic regression estimation on the crosssectional data, we identify the most important factors affecting the export activity of domestic FinTech companies. Our results have shown that FinTech companies active in Hungary can be divided into three distinct clusters based on the company characteristics involved: export share, headcount and various financial indicators. Regarding the three clusters, medium-sized companies make up half of the cluster in the group of FinTech companies with the highest export share, and the group is characterised by high value added relative to balance sheet totals. Based on our logistic regression estimation, among the FinTech companies we examined, a significantly positive effect on the probability of exporting can be identified in the case of value added, headcount and foreign ownership.

Journal of Economic Literature (JEL) codes: G23, G3, L26, O33

Keywords: FinTech, export, cluster analysis

\section{Introduction}

Digital financial services are becoming an increasingly vital part of modern financial systems. The FinTech sector is also growing dynamically on a global scale: it is characterised by more and more customers and an ever-wider range of products. This trend is reinforced by special demand, supply and technology factors as well

* The papers in this issue contain the views of the authors which are not necessarily the same as the official views of the Magyar Nemzeti Bank.

Péter Fáykiss is a Director at the Magyar Nemzeti Bank. Email: faykissp@mnb.hu Livia Ónozó is an Analyst at the Magyar Nemzeti Bank. Email: onozol@mnb.hu

The Hungarian manuscript was received on 16 June 2020.

DOI: http://doi.org/10.33893/FER.19.4.6082 
(MNB 2020). To many people, FinTech companies today still appear primarily as end-user, consumer service enterprises, but it is becoming increasingly apparent that a significant group of them are basically serving business users and other enterprises.

In this study, the term "FinTech" is essentially used according to the definition of the Financial Stability Board (FSB) ${ }^{1}$ (FSB 2017), i.e. FinTech companies are considered to be enterprises providing technology-oriented innovations that result in new business models, applications, processes or products with an material impact in the financial services sector. Thus typically, they are technology-focused enterprises that either provide some kind of technological solution in an element or elements of the value chain for financial services institutions, or provide services for end-users in connection with a financial product. However, this does not necessarily mean it can only be a service that can be provided with supervisory permission. There are several areas where FinTech companies provide services that are not subject to permission. Different definitions can of course be found in academic literature (see, among others, Arner et al. 2015 or Kim et al. 2016). In our analysis, we have considered the increasingly dominant FSB definition to be the guiding principle.

According to data of the Central Bank of Hungary (Magyar Nemzeti Bank, MNB), in 2018 there were more than 110 FinTech companies in Hungary. The domestic FinTech sector employed about 5,000 people based on the data of 2018 accounts, and their total annual revenue was close to HUF 120 billion. The vast majority of these companies basically provided a "business to business" service, i.e. they focused primarily on business customers. The profitability of the entire sector was high, mainly due to larger, often foreign-owned enterprises. The sector has seen strong growth in recent years, with both revenue and the number of employees increasing substantially (MNB 2020). Although the current size and national economic weight of the domestic FinTech sector (below 5 per cent) is dwarfed compared to the entire financial, insurance and information-communication sections ${ }^{2}$, it can still be considered an important segment for two reasons. First, these companies often have high value added and thus they may be able to engage in significant export activity, which can be a key factor for growth. Second, the competitive technological solutions they use can not only improve their own efficiency, but by becoming integrated into the value chain of financial services, they can also strengthen and catalyse the competitiveness of the entire domestic financial system, which can also have a positive impact on economic growth through lending and other financial services.

\footnotetext{
1 "FinTech is defined as technology-enabled innovation in financial services that could result in new business models, applications, processes or products with an associated material effect on the provision of financial services" (FSB 2017:7).

${ }^{2}$ STADAT - 3.1.4. Value and distribution of gross value added by industries (1995-). https://www.ksh.hu/ docs/eng/xstadat/xstadat_annual/i_qpt002d.html
} 
In the context of the FinTech phenomenon, international academic literature focuses primarily on the main driving forces in relation to the field and the potential challenges to the financial system (see, among others, Arner et al. 2015; King 2014; Lee - Shin 2018; Varga 2017; and a useful summary about the FinTech field and possible future research directions: Goldstein et al. 2019). Another important direction in literature is the aspect of regulation for FinTech companies and its policy implication (e.g. Douglas 2016; Anagnostopoulos 2018; Buchak et al. 2018; Fáykiss et al. 2018; Müller-Kerényi 2019). Only a smaller part of research deals with a deeper, country-focused analysis of FinTech companies (e.g. Bhandari 2016; Jutla-Sundararajan 2016), and an even smaller part uses micro-level data, in most cases due to the lack of appropriate databases. In the latter area, the study by Gai et al. (2018) focuses on the Chinese FinTech ecosystem, while Gazel - Schwienbacher (2020) examine the formation of geographic clusters by using data from about 1,000 French FinTech companies. In addition, it is worth mentioning the analysis by Eickhoff et al. (2017) and that by Gimpel et al. (2018). The former identified different FinTech business models based on micro-level data, while the latter carried out a taxonomy of FinTech companies with a "business to customer" focus by using a combination of quantitative and qualitative methodologies.

In our analysis, we examine domestic FinTech small and medium-sized enterprises by using micro-level data, focusing on a less well-known but rather important dimension of the domestic FinTech sector: the export activity of these enterprises. The purpose of our analysis is firstly to identify and briefly describe the distinct groups of domestic FinTech companies on the basis of different company characteristics (headcount, export activity, financial data), taking into account their export activity, and secondly, by using regression estimations on cross-sectional data, to identify the most important factors affecting the export activity of domestic FinTech companies and the relative role of these factors.

The examination of the export activity of domestic FinTech SMEs is relevant because, although Hungary is very active in foreign trade, the proportion of domestic value added in exports is moderate. Domestic exports are concentrated in a relatively limited range, typically in large companies, and products competitive in external markets are highly dependent on the imported goods used. The SME sector accounts for only about 20 per cent of Hungary's foreign trade turnover, while a significant reserve can be identified for increasing the number of exporting SMEs (MNB 2019). The MNB's Competitiveness Programme proposed that the goal should be to increase the number of exporting SMEs by a further 10,000 from the current 32,000 , and to increase the domestic value-added content of exports substantially. Increasing export activity is one of the most obvious growth opportunities for a FinTech company; the cross-border sale and provision of typically online, technology-based services is feasible - especially for companies with a business-to-business model -, while the global market for financial services 
offers a huge opportunity (see, among others, MNB 2020; Dietz et al. 2015; Arner et al. 2015; Lee -Shin 2018; Gimpel et al. 2018).

Companies producing for the export market face a number of challenges, and this is especially true for small and medium-sized enterprises. The decision about whether a company enters the export market is very much a managerial decision on the one hand, which financial variables are often less able to capture (see, for example, Miesenblock 1988; Bijmolt - Zwart 1994). On the other hand, however, it is essential for the given company to have a certain level of productivity and value-added to be able to cover any additional costs associated with exports (in this regard, see Melitz 2003, among others). Although this element is typically present in the case of FinTech companies using relatively advanced technology, we will show later that this factor is important in this segment as well in terms of the evolution of export activity. In our study, using a database that can be considered quite unique, we attempt to get to know the factors driving the export activity of domestic FinTech companies, to determine the dimensions specific to the group of domestic FinTech companies with stronger export activity, and we identify the relative role of these factors. The main contribution of our study is offering a detailed analysis of the clustering of domestic FinTech SMEs, taking export activity into account as well, and identifying the most important factors affecting the export activity of domestic FinTech SMEs by using logistic regression estimation on the cross-sectional data available to us.

In the next part of our study, we briefly describe how the examined domestic FinTech companies were identified and how our examined sample was put together. In the third part, we briefly review the range of data used, while in the fourth, we present the examined variables for domestic FinTech small and medium-sized enterprises. In the fifth part of our study, we briefly present whether, in the case of Hungarian FinTech enterprises, a relationship between the ownership structure and the service ranges of these FinTech companies can be identified. After that, we perform a cluster analysis of domestic FinTech companies with special regard to the export activity of the examined companies. In the seventh part, we identify the most important factors affecting the export activity of domestic FinTech companies and the relative role of these factors. The final part of the study contains the conclusions.

\section{Identification of domestic FinTech companies}

In order to carry out a deeper analysis of the export activity of Hungarian FinTech companies, it is important to identify companies that can be considered domestic FinTech companies. In our analysis, we used the definition developed by the Financial Stability Board to determine the range of services considered FinTech. As indicated above, according to the FSB's relatively broad definition, FinTech comprises financial-related services based on technology solutions that result in 
new business models, processes, applications or products (FSB 2017). Such activities include, among others, mobile banking, investment advisory via digital platforms, blockchain-based solutions, cryptocurrencies, cybersecurity and other technology solutions in financial fields, financial software development and system integration.

When compiling our examined sample, we only took into account companies registered in Hungary with a Hungarian tax number. From these, based on the NACE II classifications, companies with core activities of information technology and information services, registered as partnerships in Hungary, can constitute the basis for identifying FinTech companies. In 2019, we found roughly 15,000 enterprises engaged in such activities. Their websites were located with the help of Bing Web Search and Google Search API (for more details on the identification method used, see MNB 2020, Box 3). In addition to these NACE II classifications, the possibility of using other ones (e.g. management consulting services, auditing activity, other technical activities) may arise, but on the one hand they are related to FinTech activities on a much more distant basis, and on the other hand, domestic companies typically have several NACE II classifications. Thus the number of FinTech enterprises that may have been omitted due to the collection based on a somewhat narrower NACE II classification is quite low, also bearing in mind that, during the collection, other sources of information were used as well to check for any missing FinTechs (CB Insights, Crunchbase).

By collecting terms related to FinTech services, a database in English and Hungarian was compiled. In the corpus formed from the text of the websites found relevant and then collected, the results can be ranked according to the frequency of occurrence of the terms (adjective-noun structures) in the database. Based on the websites with the best results, a list of companies with some 300 items can be generated, of which about 110 FinTech enterprises can be identified in Hungary after filtering for the activity meeting the definition of FSB (2017) (MNB 2020).

\section{Range of data used in the analysis}

As indicated above, the database we used only contained enterprises with a Hungarian tax number. To ensure our analysis would not be distorted by larger companies that may have been active even in several service areas, from the identified FinTechs we filtered out the companies that could not be classified as micro-, small and medium-sized enterprises. The size of the companies was based on the composite classification established in practice, i.e. by taking into account the limits for balance sheet total, revenue and headcount. To define company size categories, we applied the definition used by the European Commission ${ }^{3}$, i.e. we took into account the following thresholds for balance sheet total, revenue and

\footnotetext{
${ }^{3}$ See details: https://op.europa.eu/en/publication-detail/-/publication/79c0ce87-f4dc-11e6-8a3501aa75ed71a1
} 
headcount: micro-sized enterprises are those that employ fewer than 10 people and whose annual turnover or balance sheet total does not exceed EUR 2 million; small enterprises are those with between 10 and 49 employees, and up to EUR 10 million in revenue or balance sheet total; while medium-sized enterprises are companies with less than 250 employees and annual revenue of less than EUR 50 million or a balance sheet total of less than EUR 43 million.

In our analysis, from the companies in the domestic FinTech sector, we took into consideration the micro-, small and medium-sized enterprises that were active in 2019. Following the data filtering indicated above, our database contained a total of 104 companies. FinTech companies active in Hungary were basically examined in light of their annual accounts. This made it possible for us to analyse the economic activity and size of companies, and within the FinTech sector, to identify distinct groups taking export activity into account as well. Where data may have been incomplete in the annual accounts, we also used the OPTEN company directory as a secondary database. Generally speaking there were essentially no extreme outliers in the analysed database, but if outliers occurred for a given variable, this is indicated separately at the given place.

\section{Variables examined for domestic small and medium-sized FinTech enterprises}

Based on their activities and annual accounts, FinTech companies included in the examination were essentially examined based on 10 variables, which in our view cover the most important dimensions of these companies as well as possible in light of the available data. As categorical variables, (i) the ownership background (domestic or foreign), (ii) the business focus ("business to business" or "business to customer") and the broader (iii) range of services of the given enterprise were included in the analysis. An enterprise was considered foreign-owned if the foreign ownership exceeded 50 per cent of the equity. The main business focus and main range of services of FinTech enterprises were established on the basis of NACE II numbers and the given enterprise's website. In our analysis, as numerical variables, we used (iv) exports relative to total revenue, ( $v$ ) the number of employees, indicating the size of the company, (vi) equity and (vii) short-term debt relative to the balance sheet total, which capture the equity ratio, (viii) the ratio of liquid funds to the balance sheet total, showing liquidity conditions and (ix) the after-tax return on sales revenue, indicating profitability, while as a variable capturing value added, $(x)$ the ratio of personnel expenses, depreciation and amortisation and after-tax profit to the balance sheet total was used. In our cluster analysis, we basically used these numerical variables.

Regarding the examination of categorical variables, domestic FinTech companies cover a rather wide range of services. Of the seven categories used, most of the FinTech enterprises in the sample are mainly active in the "Data analysis 
and business intelligence", the "Payment services" and the "Financial software development and system integration" service categories (Figure 1). Looking at the sampled FinTech companies according to their ownership background, we can see that about 73 per cent of them can be considered Hungarian-owned, while 27 per cent of them are foreign-owned companies. Although our variable based on the proportion of foreign ownership within the company can be measured on a continuous scale, the observations are typically around 0 and 100 per cent, which enabled classification into domestic and foreign groups. In addition, due to the concentration around the two extremes, cutting at 50 per cent does not cause any distortion in the data. Finally, based on the main business focus, the vast majority of domestic FinTech SMEs, about 85 per cent, are basically "business to business" enterprises, i.e. essentially offer services to other enterprises, and only 15 per cent of them provide primarily "business to customer" services, i.e. services focused on end-users and consumers. It is worth noting that, both in terms of service range and ownership background, as well as main business focus, the distributions in the FinTech sample narrowed down by us to small and medium-sized enterprises differ only slightly from the distributions observed over a wider range of data in the FinTech and Digitalisation Report (MNB 2020).

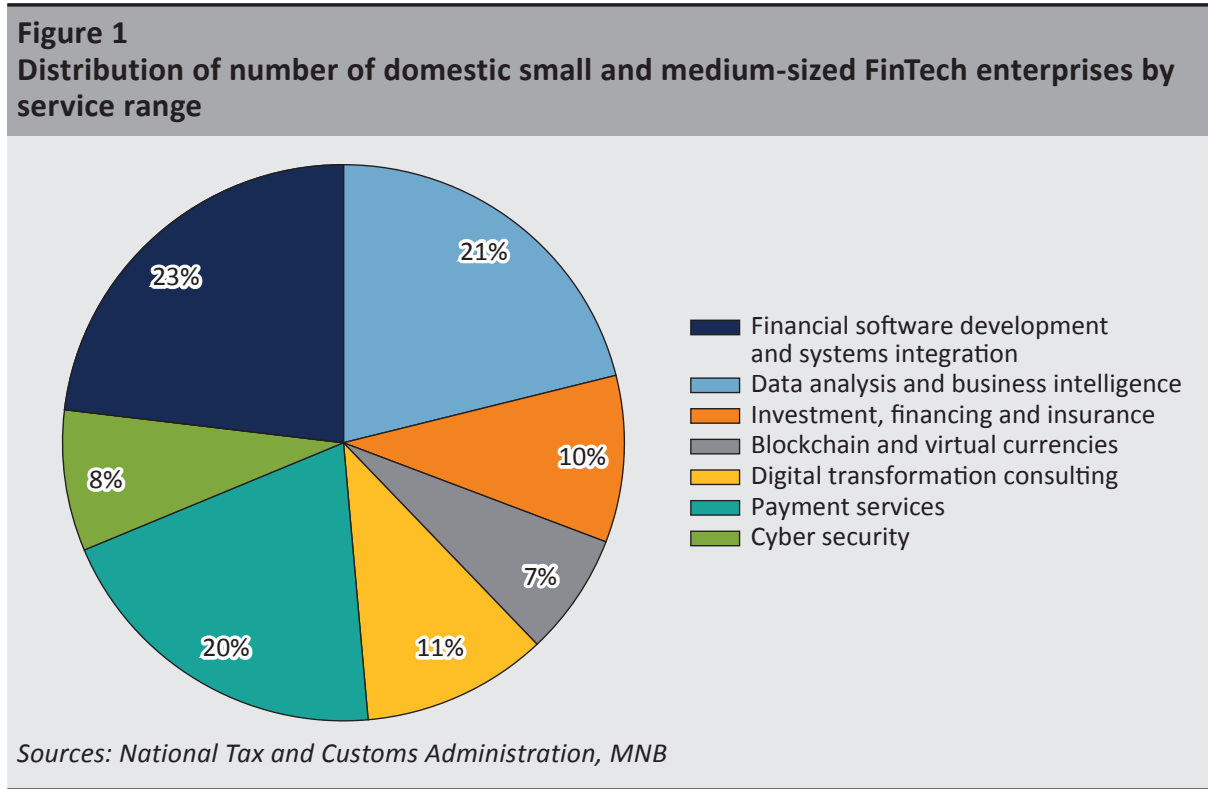

The most important descriptive statistics of the numerical variables used in our analysis are presented in Table 1. In terms of the export ratio, the examined companies are characterised by a significant standard deviation: although the average ratio is about 32 per cent, the median is only 5 per cent and the standard deviation is 40 per cent. As for the export ratio distribution, there are essentially two 
extremes: the very low export ratio below 10 per cent (typically smaller enterprises) and the very high export activity of up to even more than 90 per cent (Figure 2). Unfortunately, the database available did not contain information on the direction and depth of export activity, and thus for the FinTech companies examined there is no data on which countries, exactly how many types and what products are exported and whether entries to an export market and exits therefrom can be identified.

In terms of headcount, the average is 30 people, the standard deviation is 43 people, while half of the companies in our sample have more than 13 employees, so in line with our expectations, there are many smaller start-ups. The ratio of equity, short-term debt and liquid funds to the balance sheet total shows that the examined FinTech companies basically finance themselves from equity and typically have a financing and liquidity policy that can be considered conservative, although substantial extremes can also be identified in this area. With regard to the profit relative to revenue, it can be concluded that a notable number of the companies make losses, as the average is around -14.5 per cent. Since there are a lot of smaller start-up FinTech enterprises in the sample, this is not so surprising. Moreover, interestingly, the median is $\mathbf{7 . 5}$ per cent, i.e. half of the companies are already generating a substantial profit relative to revenue, with a significant standard deviation of course. Finally, we can also see a remarkable standard deviation for the variable used as an element to capture value added, produced from the ratio of personnel expenses, depreciation and amortisation and after-tax profit to the balance sheet total. Nevertheless, both the average (about 79 per cent) and the median value (61 per cent) suggest that a significant part of domestic FinTech SMEs can generate substantial value added.

\section{Table 1}

Descriptive statistics of domestic FinTech companies in the sample

\begin{tabular}{l|c|c|c|c|c} 
& Average & $\begin{array}{c}\text { Standard } \\
\text { deviation }\end{array}$ & Median & Minimum & Maximum \\
\hline Export ratio (\%) & 31.88 & 40.11 & 5.36 & 0 & 100 \\
\hline Headcount (persons) & 29.97 & 43.10 & 13.00 & 1.00 & 236.00 \\
\hline Ratio of equity to balance sheet total (\%) & 48.95 & 29.36 & 50.15 & -52.22 & 98.65 \\
\hline $\begin{array}{l}\text { Ratio of short-term debt to balance sheet } \\
\text { total (\%) }\end{array}$ & 36.88 & 24.20 & 31.86 & 1.32 & 97.88 \\
\hline $\begin{array}{l}\text { Ratio of liquid funds to balance sheet } \\
\text { total (\%) }\end{array}$ & 33.51 & 28.77 & 24.01 & 0.11 & 97.58 \\
\hline Profit relative to revenue* (\%) & -14.57 & 102.89 & 7.49 & -665.65 & 75.93 \\
\hline \begin{tabular}{l} 
Value added (\%) \\
\hline
\end{tabular}
\end{tabular}

Note: When compiling descriptive statistics for the variable marked with an asterisk, an enterprise qualifying as an outlier was not considered.

Sources: National Tax and Customs Administration, MNB 


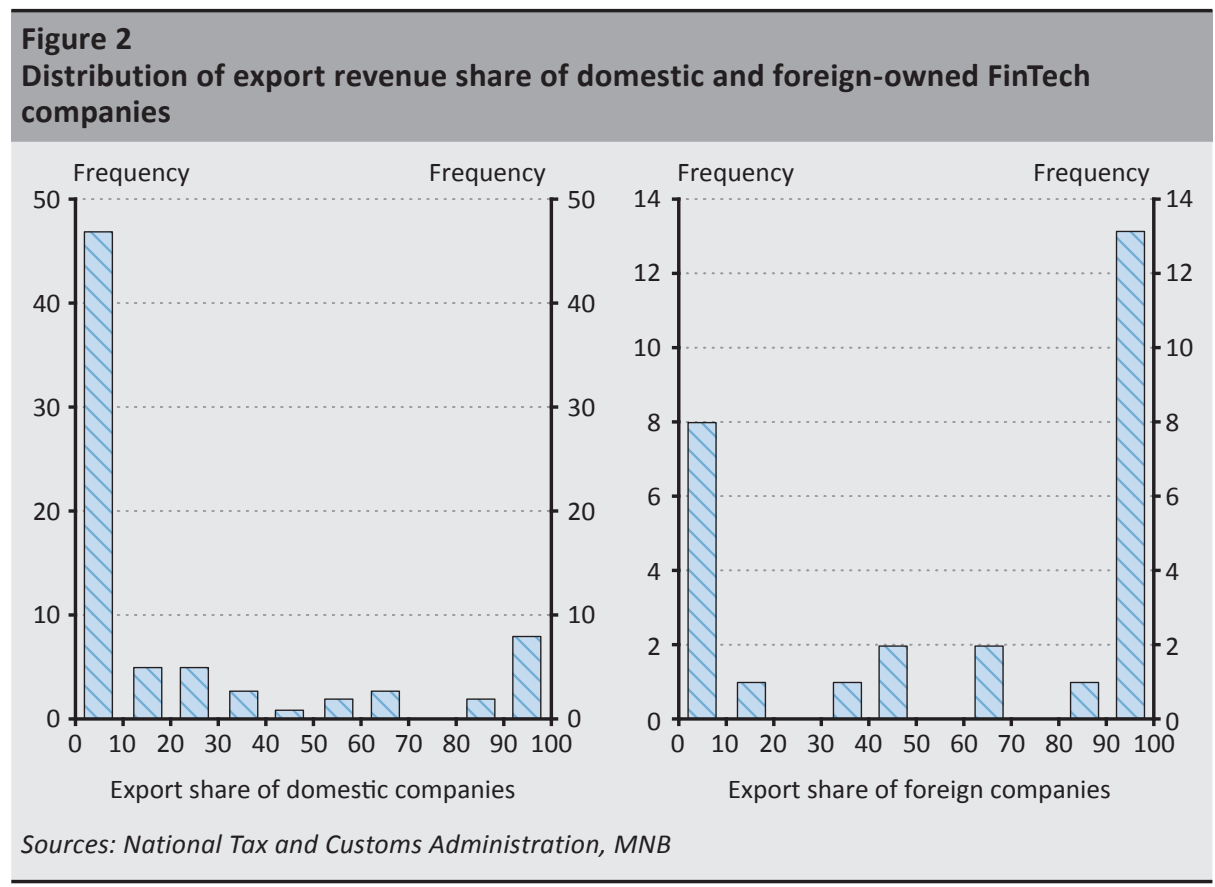

\section{Ownership background and range of services}

Below, we briefly review whether FinTech enterprises with different ownership backgrounds can be more active in certain service ranges. We basically relied on cross-table analysis here. We examined the relationship between the two categorical variables with a Chi-square test. Since the cross-table analysis of the FinTech companies in our sample had fewer than 5 observations in about 28.6 per cent of the cells, we also used the Fischer Exact test for the analysis, which is more applicable for a smaller number of elements.

Based on the Chi-square and the Fischer Exact tests, at a significance level of 5 per cent we can conclude there is no significant relationship between the ownership background and the service range (Table 2). A similar result can be seen in light of the Phi and Cramer V tests: no significant relationship between these categorical variables can be identified (see Annex). So in view of this, no significant relationship between the ownership background and the service range for domestic FinTech SMEs in our sample can be detected, i.e. in the case of foreign majority-owned FinTech companies operating in Hungary, there is a similar distribution of activity in the service ranges as in the case of domestically-owned FinTechs. 


\section{Table 2}

Results of Chi-square and Fisher Exact tests for the relationship between ownership background and service range of domestic FinTech SMEs

\begin{tabular}{l|c|c|c|c} 
& Value & df & Asymptotic sig. (2-sided) & Exact sig. (2-sided) \\
\hline Pearson Chi-square test & $4.279^{\mathrm{a}}$ & 6 & 0.592 & 0.639 \\
\hline Fischer Exact test & 4.545 & & & 0.619 \\
\hline $\mathrm{N}$ & 104 & & & \\
\hline
\end{tabular}

Note: a) In 4 cells (28.6\%), there are fewer than 5 observations. For both tests, the null hypothesis assumes that the two variables are independent.

\section{Cluster analysis of domestic FinTech SMEs}

After presenting the examined variables and examining the relationship between the ownership background and the service range, we performed a cluster analysis among the domestic small and medium-sized FinTech enterprises to identify the most important groups of domestic FinTech companies, based on different examined variables, especially the companies' export activity. In the cluster analysis, our intention is that, based on the different variables, the variance within the clusters should be as low as possible, while the variance between the clusters should be high. During cluster analysis, we have no a priori information about the observation groupings. We consider a cluster good if the companies in each group are similar, while they differ markedly from the elements of another group. In this case, by including data obtained from the companies' annual accounts, we would like to get an idea of how domestic FinTech companies can be grouped, especially with regard to their export activity.

As we are dealing with an exploratory analysis here, it is important to note that no general conclusion can be drawn from our sample about the population. What cluster a company falls into depends largely on the procedure chosen, and thus there are many other solutions besides the ones we have described. In our analysis, we performed clustering with the help of the K-means partitioning algorithm and hierarchical cluster analysis. In the case of the K-means analysis, the optimal number of clusters was determined by the so-called "elbow" method, in which the variances within the groups were compared with the variance between the groups for the different cluster numbers. The quotients thus obtained are called "cluster elbow" indicators. By plotting them as a function of cluster numbers, the optimal cluster number can be identified based on the greater slope change of the indicator. In addition to minimising proximity (i.e. variance) within the clusters and maximising distance between the clusters, the definition of three clusters was considered optimal. 
For the variables included in the cluster analysis we used the export share, which is the ratio of export revenue to total revenue; the equity ratio, i.e. the ratio of equity to the balance sheet total; value added as a percentage of the balance sheet total; the short-term debt ratio, i.e. the ratio of current liabilities to the balance sheet total; after-tax profit relative to revenue; the headcount; and the ratio of the company's liquid funds to the balance sheet total. Before clustering, we standardised the examined variables. The K-means decomposition, calculated with seven variables, breaks down the 104 companies examined on the basis of 2018 data into three distinct clusters. Below we present these three groups in more detail.

Of the three clusters, the one with the smallest number of elements ( 22 companies) includes the FinTech companies with the highest export share (Cluster 2). 90 per cent of the group's members have export revenue relative to sales revenue exceeding 90 per cent. By size category, 50 per cent of the cluster are medium-sized companies. This group is characterised by high value added relative to balance sheet total. By ownership structure, the proportions for the companies are roughly equal: 13 foreign-owned and 9 Hungarian companies were included in the cluster. Although we did not utilise the database panel feature during the analysis, we can observe a general trend that the export activity of FinTech companies included in this cluster increased steadily from 2015 to 2018.

The export performance of the other two clusters is below that of the companies in the previous group. The first cluster includes high-capital - mainly micro-sized and small - companies. In line with their high equity ratio, these companies have the lowest ratio of current liabilities to the balance sheet total. Looking at the share of foreign-owned companies within the group, we can clearly see that these companies are overrepresented here. Despite the typically foreign ownership, the companies included here usually export less, and half of them have no export revenue at all. The average headcount in this cluster is the smallest, and the value added is also relatively low compared to the total sample.

The third group consists mainly of smaller, Hungarian-owned companies with lower capital adequacy. Only a small percentage of the revenue of these observations comes from export activity; 78 per cent of the companies have less than a 20 per cent export share. The group's members are characterised by a predominantly domestic ownership structure, and the value added in this cluster is the lowest compared to the total sample. The members of this cluster have the highest ratio of current liabilities to balance sheet total. 


\section{Table 3}

Averages and standard errors of K-means cluster analysis

\begin{tabular}{l|c|c|c|c|c|c}
\multicolumn{1}{c|}{ Cluster } & \multicolumn{2}{c|}{1} & \multicolumn{2}{c|}{2} & \multicolumn{2}{c}{3} \\
\hline $\mathrm{N}$ & \multicolumn{2}{c|}{46} & \multicolumn{2}{c}{22} & \multicolumn{2}{c}{36} \\
\hline & centroid & st. error & centroid & st. error & centroid & st. error \\
\hline Export share & -0.2660 & 1.0319 & 1.3310 & 0.7724 & -0.4736 & 0.8601 \\
\hline Equity ratio & 0.8362 & 0.7156 & -0.2548 & 0.8589 & -0.9128 & 0.8400 \\
\hline $\begin{array}{l}\text { Value added (relative to } \\
\text { balance sheet total) }\end{array}$ & -0.3011 & 0.6544 & 1.2693 & 0.6836 & -0.3910 & 1.4704 \\
\hline $\begin{array}{l}\text { Number of employees } \\
\text { Vurrent liabilities }\end{array}$ & -0.2958 & 0.6851 & 0.9450 & 0.7362 & -0.1996 & 1.7019 \\
\hline $\begin{array}{l}\text { (relative to balance } \\
\text { sheet total) }\end{array}$ & -0.7396 & 0.7058 & 0.3725 & 1.0779 & 0.7174 & 1.1031 \\
\hline $\begin{array}{l}\text { After-tax profit (relative } \\
\text { to revenue) }\end{array}$ & -0.1221 & 1.7146 & 0.1044 & 0.5203 & 0.0922 & 0.5867 \\
\hline $\begin{array}{l}\text { Liquid funds (relative to } \\
\text { balance sheet total) }\end{array}$ & -0.0027 & 1.1770 & -0.5053 & 0.6329 & 1.2438 & 0.8920 \\
\hline
\end{tabular}

Based on the examination, companies can be classified into relatively distinct groups according to the selected variables (Figure 3), which is well illustrated by the cluster centroids shown in Table 3. Companies with the same export share have been placed in the same clusters. To get a more nuanced picture, for the purpose of robustness testing, we also performed a cluster decomposition on the population of companies operating in 2017. Here, after filling data gaps and filtering outlier values, we involved 95 companies in the analysis. For this sample, too, we estimated the optimal cluster number at 3. Furthermore, the 2017 groups of companies have similar characteristics to what the clusters received in 2018 have. Table 4 summarises the export share of each cluster by company size category in the two years examined. The export proportion in clusters 1 and 3 shows a slightly different pattern for medium-sized enterprises in the two years, yet the division indicates that for export activity we obtained similar results in terms of decomposition by company size in the case of micro-sized and small enterprises; those with typically high export revenue relative to turnover are in one group, those with a medium or lower export share are in a separate cluster, while enterprises with a particularly low export share have been included in the third group. 
Figure 3

K-means clusters by export share, equity ratio and value added relative to balance sheet total, 2018
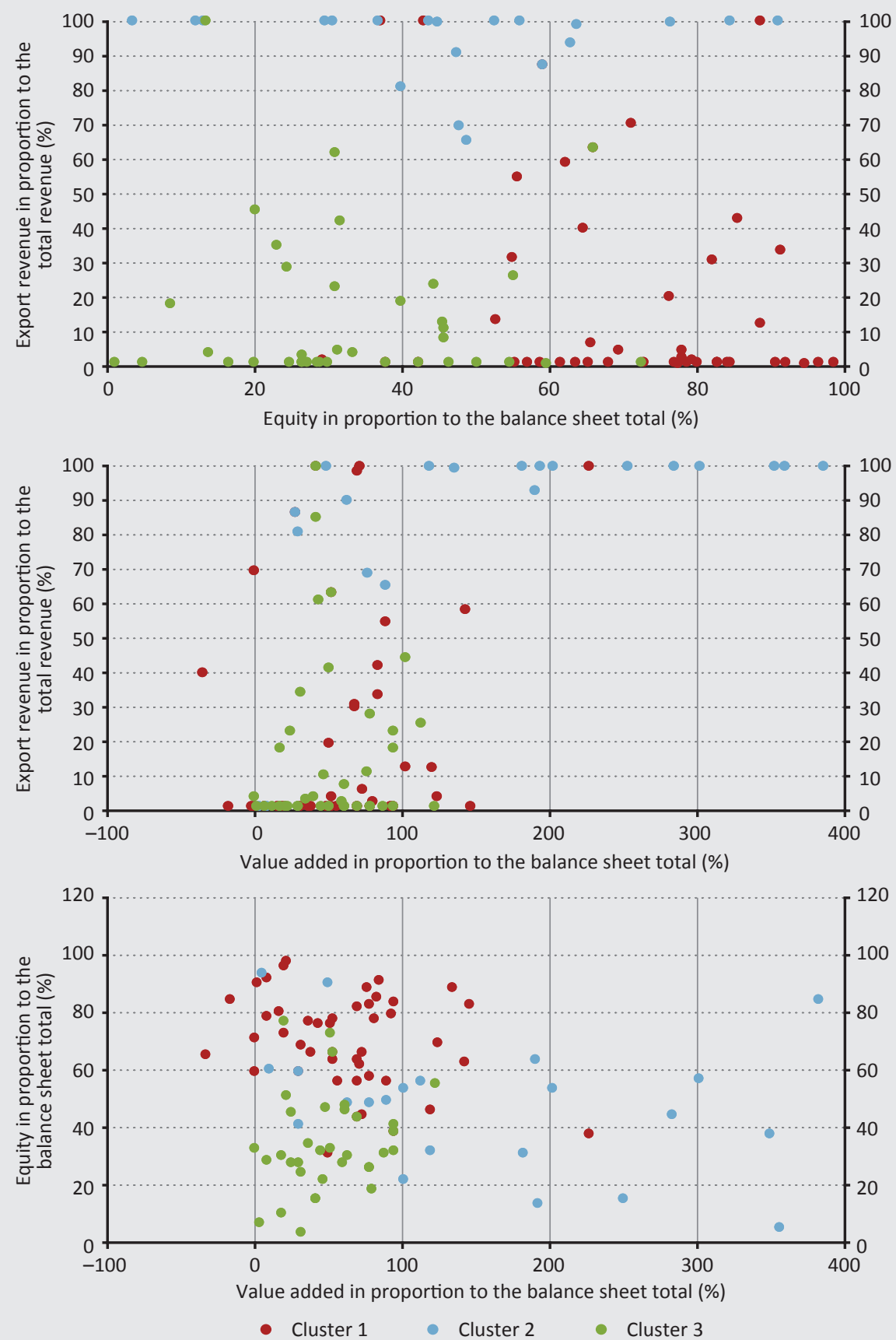

Sources: National Tax and Customs Administration, MNB 


\section{Table 4}

Average (unweighted) export proportion of domestic FinTech companies by cluster, in 2017 and 2018 (\%)

\begin{tabular}{l|c|c|c|c|c|c} 
& \multicolumn{4}{|c|}{2017} & \multicolumn{3}{c}{2018} \\
\hline Cluster & 1 & 2 & 3 & 1 & 2 & 3 \\
\hline $\mathrm{N}$ & 23 & 26 & 46 & 46 & 22 & 36 \\
\hline Micro-sized & 30.2 & 99.7 & 3.5 & 23.5 & 98.1 & 3.2 \\
\hline Small & 27.7 & 90.2 & 5.2 & 19.9 & 100.0 & 14.4 \\
\hline Medium-sized & 55.1 & 90.4 & 10.5 & 12.7 & 70.6 & 17.9 \\
\hline
\end{tabular}

Sources: National Tax and Customs Administration, MNB

We also performed an agglomerative hierarchical cluster analysis of companies, whereby clusters were formed using the Ward method, considered the hierarchical equivalent of the K-means centroid method. As a starting point for the hierarchical method, each company is placed in an independent cluster, and then the groups close to each other are merged until a large cluster is formed. Apart from the first and last steps of the algorithm, intermediate group mergings bear meaning in the development of homogeneous groups. During the analysis, here too the input variables were brought to a common scale by standardisation, and then the squared Euclidean distance of the observations was measured. In the case of the Ward method, the groups are merged in such a way that the squared error resulting from the merging is the smallest (Hair et al. 2009). Taking into account the comparability aspect, we chose the three-cluster structure. Hierarchical (clustersubcluster) relationships are represented by a dendrogramme (Figure 4).

\section{Figure 4 \\ Dendrogramme of hierarchical cluster analysis}

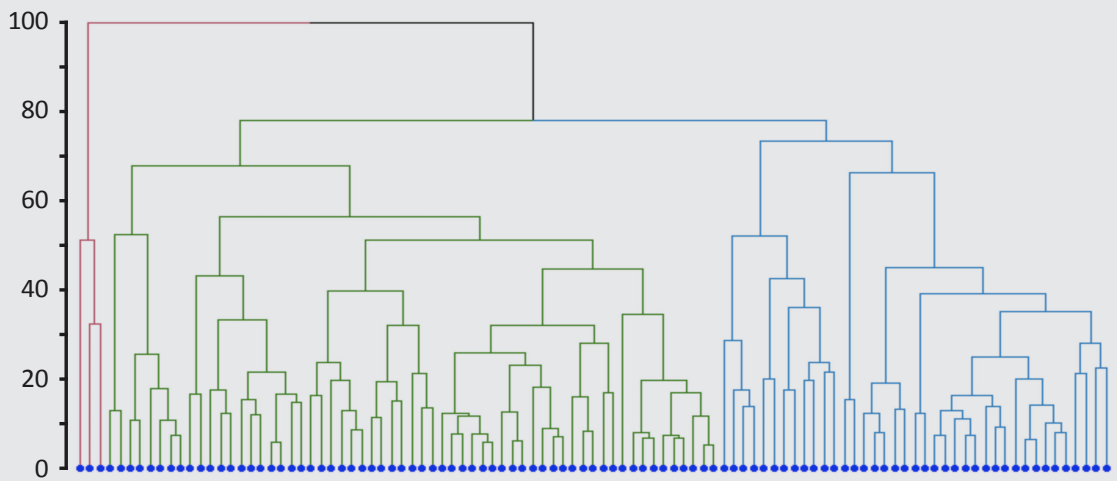

Note: The different colours represent clusters.

Sources: National Tax and Customs Administration, MNB 
For the hierarchical clustering procedure, in addition to the continuous variables used in the K-means algorithm, we also used the categorical variable of company age. The age variable available to us can take on four values depending on whether the company has been operating for at least 1, 2, 3, or rather 4 or more years. The age category has proved to be an important variable, but 75 per cent of the companies started operating before 2015, i.e. at least 4 years ago, and thus knowing the actual age of the companies would provide an opportunity for deeper examinations. The results of both clustering practices have categorised companies with a relatively high export ratio into one group, which confirms our assumption that among the analytical aspects of FinTech companies, the issue of delivering services to foreign markets is decisive. In the case of hierarchical clusters, companies operating for at least 2 years, producing mainly for the export market, with exceptionally high value added relative to the balance sheet total and belonging more to the middle-sized category were placed in the group with the highest population (see Annex). Outside the large group of 60 per cent of companies, other companies are significantly more dispersed along the variables. 39 companies ended up in the cluster, which shows a significant standard deviation both in terms of company age and the number of employees. At the same time, this group has the highest equity relative to balance sheet total. Within this group, the average export proportion is 25 per cent. Companies in the smallest cluster account for only 3 per cent of the data. The common feature of the companies here is that they produce for the domestic market, have been operating for 1-2 years and lag behind the two larger groups both in terms of value added and their equity-based indicators. As the observations were less distinct during the hierarchical cluster decomposition - almost two thirds of the companies form one cluster -, based on the comparison, we see the K-means methodology as better for the cluster analysis of domestic FinTech companies.

\section{Examination of export activity based on logistic regression estimation}

In order to examine export activity, we estimated a logistic regression on the 2018 cross-sectional data, which will be discussed in detail below. We performed our estimates on the company-level database of FinTech companies described above. Due to the relatively low number of observations, our model lags behind the maximally fitting models in explanatory power, but it is suitable for research purposes - such as determining the factors affecting the export activities of domestic FinTech companies and identifying their relative weight -, i.e. for exploratory modelling. To create the dichotomous outcome variable required for the logit model, we converted the continuous variable of export share discussed above into a binary variable. Since one of the important objectives of our analysis is to identify the factors affecting export activity among domestic FinTech enterprises, it is 
primarily necessary to separate companies not exporting at all or only to a negligible extent from FinTech enterprises already exporting to some extent. Accordingly, in our logit model, companies with an export share of more than 10 per cent, which is not considered negligible, have been categorised as exporters; they represent value 1. To separate the effect of the characteristics of the examined companies on the target variable, the following variables were included in the estimation equation: ownership structure (foreign or domestic ownership), the previous year's value added relative to balance sheet total, headcount, long-term liabilities, company age and the square of the age variable. To eliminate endogeneity problems, the 2017 figure of value added relative to balance sheet total was included in the explanatory variables.

The model specification for logistic estimation is as follows:

$$
\begin{aligned}
P(\text { exporter }= & 1 \mid X) \\
& =\Lambda\left(\text { constant }+\beta_{1} \text { ownership structure }+\beta_{2}\right. \text { L.value added } \\
& +\beta_{3} \text { number of employees }+\beta_{4} \text { ratio of long-term liabilities } \\
& \left.+\beta_{5} \text { age }+\beta_{6} \text { age }{ }^{2}\right)
\end{aligned}
$$

where:

$$
\Lambda(z)=\frac{1}{1+e^{-z}}
$$

The results of our estimation are summarised in Table 5. In general, the signs of the variables involved are in line with the hypotheses discussed above, i.e. higher value added relative to balance sheet total and long-term liabilities increase the probability of becoming an exporter. Looking at the ownership structure, we can see that, at a 5 per cent significance level, there is a positive relationship between foreign ownership and the probability of falling into the exporting category (this identified effect is also indicated by the result of the Mann-Whitney $U$ test examining the relationship between ownership structure and export activity [Hair et al. 2009; Kovács 2014]; see Annex). For company age and age square, we have not found sufficient statistical evidence that the coefficient of the variables significantly differs from zero. Based on our tests, the estimated coefficient of the value added differs from zero at all standard significance levels. The parameter of company headcount can be considered significant at the 5 per cent level, which also positively links the higher number of employees with the probability of becoming an exporter. 


\begin{tabular}{l|c}
\hline $\begin{array}{l}\text { Table } 5 \\
\text { Results of the logit model for falling into the exporter category }\end{array}$ & P (Exporting = 1) \\
\hline Explanatory variables & $1.133^{*}$ \\
\hline Foreign ownership & {$[0.580]$} \\
Value added (relative to balance sheet total, 2017) & $0.0127^{* * *}$ \\
& {$[0.00480]$} \\
Long-term liabilities & $1.24 \mathrm{e}-05^{*}$ \\
Number of employees & {$[6.80 \mathrm{e}-06]$} \\
& $0.0156^{*}$ \\
Age & {$[0.00815]$} \\
Age square & 6.83 \\
Constant & {$[6.304]$} \\
Number of observations & -1.027 \\
\hline Pseudo R-squared & {$[1.033]$} \\
\hline Note: Standard errors are shown in square brackets; significance levels: *** p<0.01; ** $p<0.05 ; * p<0.1$. \\
\hline
\end{tabular}

For logistic regression, the direct effect of parameters on probabilities cannot be interpreted, only the partial effect. Table 6 shows the marginal effects calculated at the average. ${ }^{4}$ The variable of ownership structure category takes a value of 0 if the company is domestic and a value of 1 if the company is foreign-owned. In the case of the marginal effect taken at the average, it shows how much the probability of falling into the exporting category changes if the examined company is foreign (compared to a domestic company), while at the same time, the other variables assume their values taken at the average. The average marginal effect of foreign ownership is 0.2727 , which means that for two hypothetical companies with average and equal financial indicators and headcount figures relative to the balance sheet total, the probability of exporting is 0.27 higher for the foreign company than for its domestic counterpart.

\section{Table 6}

Marginal effects calculated at averages based on the logit model

\begin{tabular}{l|c|c|c|c} 
& $\begin{array}{c}\text { Average marginal } \\
\text { effect }\end{array}$ & Standard error & $\mathbf{P}>|\mathbf{z}|$ & Average \\
\hline Ownership structure & 0.2727 & 0.1283 & 0.034 & 0.27 \\
\hline $\begin{array}{l}\text { Value added (rel. to } \\
\text { balance sh. tot.) }\end{array}$ & 0.0032 & 0.0012 & 0.008 & 62.06 \\
\hline Headcount & 0.0039 & 0.0020 & 0.056 & 29.65 \\
\hline
\end{tabular}

\footnotetext{
${ }^{4}$ For binary variables, the marginal effect measures how predicted probabilities change as a result of a discrete change in our binary variable, i.e. where it takes a value of 1 instead of 0 . In the case of continuous variables, the marginal effects provide a good approximation of the change measured in the outcome variable as a result of a one-unit increase in the explanatory variable.
} 
Based on the confusion matrix calculated from the results of the logistic regression, our model correctly estimates the export activity (exporter or non-exporter) of the companies in the sample at around 77.2 per cent. The elements of the confusion matrix can be interpreted at a given cut-off value, by changing which the elements of the matrix also take on a new value (Table 7). During classification, above a probability limit of 0.5 the prediction of a given observation to fall into the exporter category was considered to be an estimated exporter.

\section{Table 7}

\section{Confusion matrix}

\begin{tabular}{l|c|c}
\multirow{2}{*}{$\begin{array}{l}\text { Estimate-based predicted value } \\
\text { of export activity }\end{array}$} & \multicolumn{2}{|c}{ Export activity based on observations } \\
\cline { 2 - 3 } & Non-exporter & Exporter \\
\hline Non-exporter & $87 \%$ & $33 \%$ \\
\hline Exporter & $13 \%$ & $67 \%$
\end{tabular}

Figure 5 shows the ROC curve, i.e. the rate of correctly predicted exporting companies relative to that of those classified erroneously as exporting companies, as a function of different cut-off values.

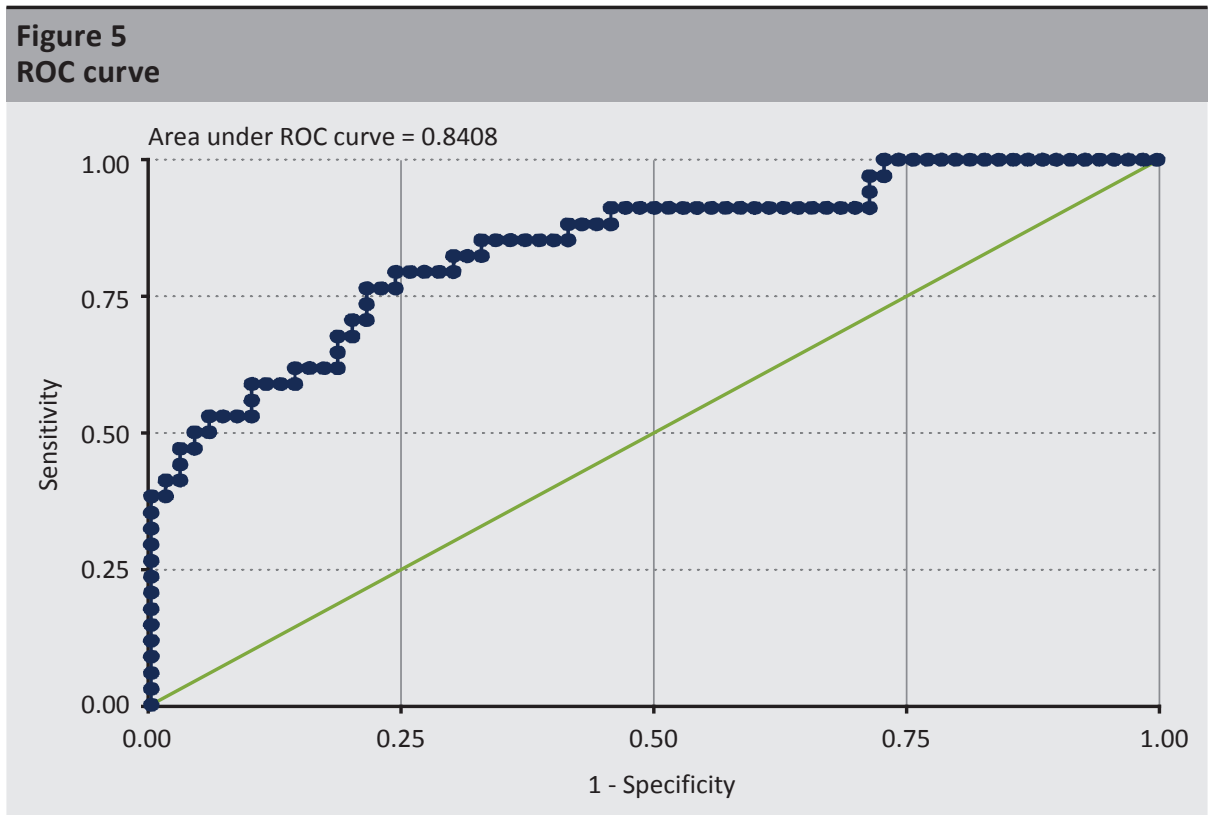




\section{Conclusions}

In our analysis, we examined domestic FinTech SMEs by using micro-data, focusing on the export activity of companies in the domestic FinTech sector. Our study offers new content not only because of the range of examined enterprises, but also due to the uniqueness of the database used, as we endeavoured to give a deeper picture of domestic FinTech companies with the help of company data rarely used thus far. Our examination had a twofold purpose: First, we identified and briefly described the distinct groups of domestic FinTech companies based on different company characteristics (headcount, export activity, financial data), and second, by using logistic regression estimation on the cross-sectional data, we identified the most important factors affecting the export activity of domestic FinTech companies.

In our study, we presented how the domestic FinTech companies examined were identified, and we briefly reviewed the range of data used. Next, we examined whether a relationship between the service range and the ownership background of domestic FinTech companies in our sample could be identified, and then, we performed a cluster analysis of domestic FinTech SMEs, with special regard to the export activity of the companies examined. Our results have shown that small and medium-sized FinTech companies active in Hungary can be divided into three distinct groups based on the company characteristics involved: export share, headcount and various financial indicators. Of the three clusters, the cluster with the smallest number of elements, 22 companies, has the FinTech companies with the highest export share. 90 per cent of the group's members have export revenue relative to sales revenue exceeding 90 per cent. By size category, 50 per cent of the cluster is made up of medium-sized companies, and the group is characterised by high value added relative to balance sheet total. Interestingly, despite the strong export activity, FinTech enterprises with a foreign ownership background are not substantially overrepresented in this cluster: the proportion of companies is roughly balanced based on ownership structure.

By estimating logistic probability models, we sought to answer the question of how certain characteristics of companies (foreign ownership, value added, headcount, etc.) had had an impact on becoming an exporting company. Looking at the ownership structure, we identified a significant positive relationship between the probability of falling into the exporter category and foreign ownership. Parameters of the value added to balance sheet total ratio and of the headcount variable also indicate a positive relationship.

The results of this analysis are also worth examining from an economic policy perspective. First, it is important to know that the domestic FinTech sector, although relatively small, can still be considered fundamentally competitive, as even in a relatively narrow, globally highly competitive segment such as the FinTech 
sector, Hungarian companies with strong export activity and high value added can be substantially identified. Second, it can be concluded from our analysis that higher value added increases the probability of FinTech companies' export activity, and thus a more active presence in the export market is expected if this factor is strengthened. This can be relevant for both domestic stimulus policy and domestic export strategy.

\section{References}

Anagnostopoulos, I. (2018): Fintech and regtech: Impact on regulators and banks. Journal of Economics and Business, 100(November-December): 7-25. https://doi.org/10.1016/j. jeconbus.2018.07.003

Arner, D.W. - Barberis, J.N. - Buckley, R.P. (2015): The Evolution of Fintech: A New Post-Crisis Paradigm? University of Hong Kong Faculty of Law Research Paper No. 2015/047. http:// dx.doi.org/10.2139/ssrn.2676553

Bhandari, M. (2016): India and the Pyramid of Opportunity. In: Chishti, S. - Barberis, J: The FinTech Book: The Financial Technology Handbook for Investors, Entrepreneurs and Visionaries, pp. 81-83. https://doi.org/10.1002/9781119218906.ch22

Bijmolt, T.H.A. - Zwart, P.S. (1994): The impact of internal factors on the export success of Dutch small and medium-sized firms. Journal of Small Business Management, 32(2): 69-83.

Buchak, G. - Matvos, G. - Piskorski, T. - Seru, A. (2018): Fintech, regulatory arbitrage, and the rise of shadow banks. Journal of Financial Economics, 130(3): 453-483. https://doi. org/10.1016/j.jfineco.2018.03.011

Dietz, M. - Olanrewaju, T. - Khanna, S. - Rajgopal, K. (2015): Cutting through the noise around financial technology. https://www.mckinsey.com/industries/financial-services/ our-insights/cutting-through-the-noise-around-financial-technology\#

Douglas, J.L. (2016): New Wine Into Old Bottles: Fintech Meets the Bank Regulatory World. Banking Institute Journal, 20(1): 17-65.

Eickhoff, M. - Muntermann, J. - Weinrich, T. (2017): What do FinTechs actually do? A taxonomy of FinTech business models. Conference Paper, International Conference on Information Systems 2017, South Korea.

Fáykiss, P. - Papp, D. - Sajtos, P. - Tőrös, Á. (2018): Regulatory Tools to Encourage FinTech Innovations: The Innovation Hub and Regulatory Sandbox in International Practice. Financial and Economic Review, 17(2): 43-67. http://doi.org/10.25201/FER.17.2.4367

FSB (2017): Financial Stability Implications from FinTech. Financial Stability Board. https:// www.fsb.org/2017/06/financial-stability-implications-from-fintech/ 
Gai, K. - Qiu, M. - Sun, X. (2018): A survey on FinTech. Journal of Network and Computer Applications, 103(February): 262-273. https://doi.org/10.1016/j.jnca.2017.10.011

Gazel, M. - Schwienbacher, A. (2020): Entrepreneurial fintech clusters. Small Business Economics. https://doi.org/10.1007/s11187-020-00331-1

Gimpel, H. - Rau, D. - Röglinger, M. (2018): Understanding FinTech start-ups-a taxonomy of consumer-oriented service offerings. Electronic Markets, 28(3): 245-264. https://doi. org/10.1007/s12525-017-0275-0

Goldstein, I. - Jiang, W. - Karolyi, G. A. (2019): To FinTech and beyond. The Review of Financial Studies, 32(5): 1647-1661. https://doi.org/10.1093/rfs/hhz025

Hair, J.F. - Black, W.C. - Babin, B.J. - Anderson, R.E. (2009): Multivariate Data Analysis. 7th Edition. Pearson.

Jutla, S. - Sundararajan, N. (2016): India's FinTech Ecosystem. In: Chishti, S. - Barberis, J: The FinTech Book: The Financial Technology Handbook for Investors, Entrepreneurs and Visionaries, pp. 56-57. https://doi.org/10.1002/9781119218906.ch15

Kim, Y. - Park, Y.J. - Choi, J. (2016): The Adoption of Mobile Payment Services for "Fintech". International Journal of Applied Engineering Research, 11(2): 1058-1061.

King, B. (2014): Breaking Banks: The Innovators, Rogues, and Strategists Rebooting Banking. New York: John Wiley \& Sons.

Kovács, E. (2014): Többváltozós adatelemzés (Multivariate data analysis). Typotex.

Lee, I. - Shin, Y.J. (2018): Fintech: Ecosystem, business models, investment decisions, and challenges, Business Horizons, 61(1: 35-46. https://doi.org/10.1016/j.bushor.2017.09.003

Melitz, M.J. (2003): The impact of trade on intra-industry reallocations and aggregate industry productivity. Econometrica, 71(6): 1695-1725. https://doi.org/10.1111/14680262.00467

Miesenblock, K.J. (1988): Small business and exporting: a literature review. International Small Business Journal, 6(2): 42-61. https://doi.org/10.1177/026624268800600204

MNB (2019): Competitiveness Programme in 330 points. Magyar Nemzeti Bank. https:// www.mnb.hu/letoltes/competitiveness-programme-in-330-points.pdf

MNB (2020): FinTech and Digitalisation Report. Magyar Nemzeti Bank. https://www.mnb. hu/letoltes/fintech-es-digitalizacios-jelente-s-final-eng.pdf

Müller, J. - Kerényi, Á. (2019): The Need for Trust and Ethics in the Digital Age - Sunshine and Shadows in the FinTech World. Financial and Economic Review, 18(4): 5-34. http:// doi.org/10.33893/FER.18.4.534

Varga, D. (2017): FinTech, the new era of financial services. Budapest Management Review, 48(11): 22-32. https://doi.org/10.14267/VEZTUD.2017.11.03 


\section{Annex}

\section{Table 8}

Examination of relationship between ownership background and service range for domestic FinTech SMEs by Phi and Cramer V tests

\begin{tabular}{l|c|c|c} 
& Value & Approx. sig. & Exact sig. \\
\hline Phi & 0.203 & 0.639 & 0.611 \\
\hline Cramer V & 0.203 & 0.639 & 0.611 \\
\hline $\mathrm{N}$ & 104 & & \\
\hline
\end{tabular}

\section{Table 9}

Normality test for export activity and ownership background

\begin{tabular}{|c|c|c|c|c|c|c|c|}
\hline \multirow[b]{2}{*}{ Export share } & & \multicolumn{3}{|c|}{ Kolmogorov-Smirnov ${ }^{a}$} & \multicolumn{3}{|c|}{ Shapiro-Wilk } \\
\hline & & Stat. & df & Sig. & Stat. & df & Sig. \\
\hline \multirow{2}{*}{$\begin{array}{l}\text { Ownership } \\
\text { background }\end{array}$} & Domestic & 0.300 & 76 & 0.000 & 0.673 & 76 & 0.000 \\
\hline & Foreign & 0.239 & 29 & 0.000 & 0.774 & 29 & 0.000 \\
\hline
\end{tabular}

Note: a) Lilliefors Significance Correction.

\section{Table 10}

Examination of relationship between export activity and ownership background of domestic FinTech SMEs by Mann-Whitney $U$ independent-sample test

\begin{tabular}{l|c} 
Total N & 104 \\
\hline Mann-Whitney U & $1,583.500$ \\
\hline Wilcoxon W & $1,989.500$ \\
\hline Test statistic & $1,583.500$ \\
\hline Standard error & 131.750 \\
\hline Standardised test statistic & 3.943 \\
\hline Asymptotic sig. (2-sided test) & 0.000 \\
\hline
\end{tabular}




\section{Figure 6}

K-means clusters by export share, equity ratio and value added relative to balance sheet total, 2018

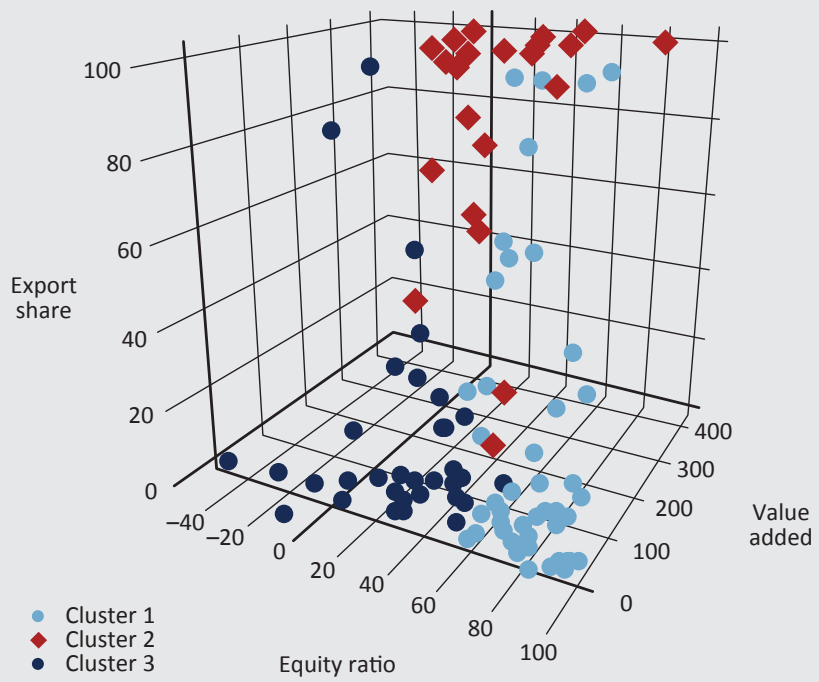

Sources: National Tax and Customs Administration, MNB

Figure 7

Hierarchical clusters by export share, equity ratio and value added relative to balance sheet total, 2018

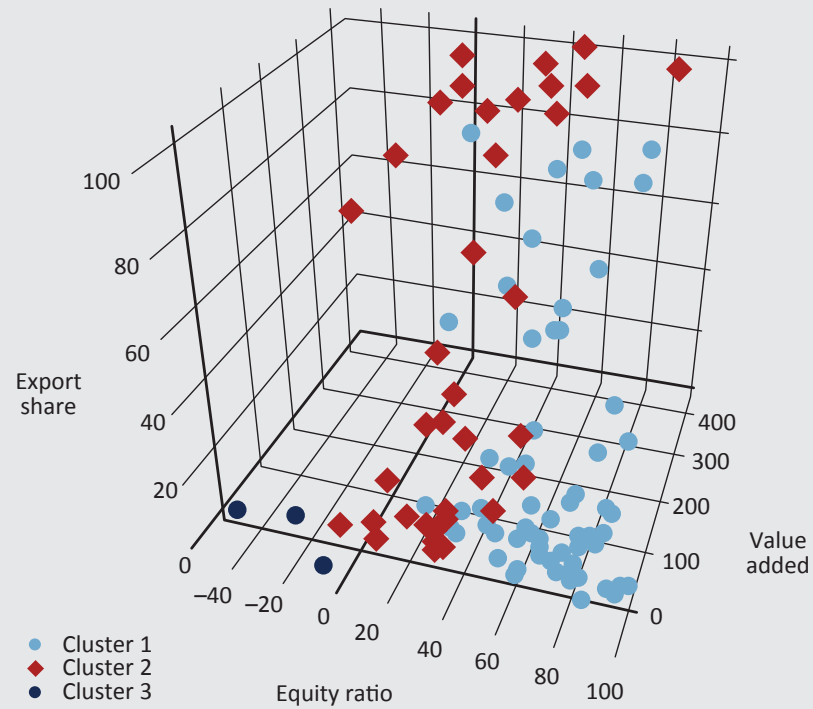

Sources: National Tax and Customs Administration, MNB 